\title{
EFFECT ON PERFORMANCE OF COMPOSITION OF Li-ION CARBON ANODES DERIVED FROM PMAN/DVB COPOLYMERS ${ }^{\sharp}$
}

\section{RONALD A. GUIDOTTI* AND WILLIAM R. EVEN**}

Sandia National Laboratories

*P.O. Box 5800, Albuquerque, NM 87185-0614, raguido@sandia.gov

**P.O. Box 969, Livermore, CA 94551

\section{ABSTRACT}

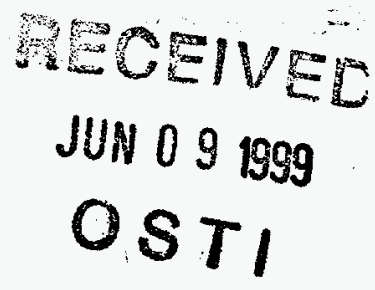

The effects on electrochemical performance of the nitrogen content of disordered carbons derived from polymethacryonitrile (PMAN)-divinylbenzene (DVB) copolymers were examined in galvanostatic cycling tests between $2 \mathrm{~V}$ and $0.01 \mathrm{~V}$ vs. $\mathrm{Li}^{2} / \mathrm{Li}^{+}$in $1 \mathrm{M} \mathrm{LiPF} /$ ethylene carbonate (EC)-dimethyl carbonate (DMC). The first-cycle reversible capacities and coulombic efficiencies increased with increase in the level of nitrogen for samples prepared at $700^{\circ} \mathrm{C}$. However, the degree of fade also increased. Similar tests were performed on materials that were additionally heated at $1,000^{\circ}$ and $1,300^{\circ} \mathrm{C}$ for five hours. Loss of nitrogen, oxygen, and hydrogen occurred under these conditions, with none remaining at the highest temperature in all cases but one. The pyrolysis temperature dominated the electrochemical performance for these samples, with lower reversible and irreversible capacities for the first intercalation cycle as the pyrolysis temperature was increased. Fade was reduced and coulombic efficiencies also improved with increase in temperate. The large irreversible capacities and high fade of these materials makes them unsuitable for use in Li-ion cells.

\section{INTRODUCTION}

A large research effort has been underway in recent years in developing suitable carbon and graphite materials for use as Li-ion anodes in ambient temperature cells using liquid organic electrolytes, as well as polymer electrolytes. The "soft", ordered graphites typically have low first-cycle capacity losses associated with solvent/salt reduction processes [1]. These materials have capacities limited by the composition $\mathrm{LiC}_{6}$, or $372 \mathrm{mAh} / \mathrm{g}$ of $\mathrm{C}$. The "hard" disordered or turbostratic carbons, on the other hand, have shown to have capacities well in excess of 372 $\mathrm{mAh} / \mathrm{g}$-sometimes increased by a factor of 1.5 or more [2]. The composition of disordered carbons has an impact on its electrochemical performance. The $\mathrm{H} / \mathrm{C}$ atomic ratio, for example, was found to correlate to the reversible capacity for some specific materials [3]. Incorporation of $\mathrm{Si}$ into the carbon lattice has also been reported to enhance the reversible capacity for select precursor materials [4]. Doping with nitrogen, however, resulted in degradation of performance, due to an increase in the irreversible capacity [5].

We have previously reported on the performance of disordered carbons derived from PMAN/DVB copolymers [6-9]. In that work, a PMAN/DVB molar ratio of 1.6:1 was used. In this paper, we present the results of electrochemical characterization of carbons derived from similar precursors, but where the PMAN/DVB ratio was varied from 0 to $3: 1$, to produce carbons with a wide range of nitrogen content. These materials were then galvanostatically cycled between $2 \mathrm{~V}$ and $0.01 \mathrm{~V}$ (at $0.5 \mathrm{~mA} / \mathrm{cm}^{2}$ ) to characterize their electrochemical performance. 


\section{DISCLAIMER}

This report was prepared as an account of work sponsored by an agency of the United States Government. Neither the United States Government nor any agency thereof, nor any of their employees, make any warranty, express or implied, or assumes any legal liability or responsibility for the accuracy, completeness, or usefulness of any information, apparatus, product, or process disclosed, or represents that its use would not infringe privately owned rights. Reference herein to any specific commercial product, process, or service by trade name, trademark, manufacturer, or otherwise does not necessarily constitute or imply its endorsement, recommendation, or favoring by the United States Government or any agency thereof. The views and opinions of authors expressed herein do not necessarily state or reflect those of the United States Government or any agency thereof. 


\section{DISCLAIMER}

Portions of this document may be illegible in electronic image products. Images are produced from the best available original document. 


\section{EXPERIMENTAL}

\section{Synthesis}

Our standard carbon precursor is synthesized as an inverse emulsion containing methacrylonitrile (MAN) and DVB monomers in a molar ratio of 1.6:1. For this work, additional ratios of $0: 1,1: 3$, and $3: 1$ were used to prepare zero- $\mathrm{N}$, low- $\mathrm{N}$, and high- $\mathrm{N}$ materials, respectively. A mixture of styrene and DVB $(1: 3 \mathrm{~m} / \mathrm{m})$ was used as precursor to prepare a second $\mathrm{N}$-free material. The polymerization was carried out using a persulfate catalyst and a $65^{\circ} \mathrm{C}$ cure for $16 \mathrm{~h}$. The resulting low-density foam was air dried, removing the water pore former, and attritted to a -400 mesh powder. The precursor powder was oxidatively stabilized in air at $240^{\circ} \mathrm{C}$ for six hours [9]. Pyrolysis took place in a $6^{\prime \prime}$-dia. tube furnace under high-purity argon flowing at $2 \mathrm{~L} / \mathrm{min}$. The samples were heated to $700^{\circ} \mathrm{C}$ at $2^{\circ} \mathrm{C} / \mathrm{min}$ and were held at this temperature for five hours. The low pyrolysis temperature was chosen because it offered the potential for improved performance of PMAN carbons. The net yield was $105-170 \mathrm{~g}$ of carbon.

Additional heating tests were conducted with the $700^{\circ} \mathrm{C}$-prepared material at temperatures of $1,000^{\circ}$ and $1,300^{\circ} \mathrm{C}$ in a graphite-heated furnace under high-purity argon. The samples were heated to the desired temperature over three hours and were then held for five hours at temperature before cooling to ambient over one hour. The samples were analyzed at Galbraith Laboratories for $\mathrm{O}, \mathrm{N}, \mathrm{H}$, and $\mathrm{C}$ (by difference).

\section{Electrochemical Characterization}

Three-electrode cells made of perfluoroalkoxy were used for testing the carbons. The electrodes were prepared by "doctor blading" a paste onto copper-foil substrates. The paste consisted of a mixture of $80 \%{ }^{1}$ carbon, $5 \%$ Super ' $\mathrm{S}$ ' carbon black (as a conductive additive), and $15 \%$ polyvinylidene difluoride (PVDF). Discs $1.27 \mathrm{~cm}(0.5$ " in) in diameter were then punched from the vacuum-dried, pasted copper sheets for use in the cells. The mass of carbon in each electrode ranged from 5 to $10 \mathrm{mg}$.

The cells were assembled in a dry room $(\mathrm{RH}<3 \%)$ and used a $\mathrm{Li}$ counter and reference electrodes and two 0.001 "-thick Celgard 2500 separator discs. The cells were transported into a glovebox $\left(<10\right.$ ppm each $\mathrm{H}_{2} \mathrm{O}$ and $\mathrm{O}_{2}$ ) where they were evacuated and backfilled with $1 \mathrm{M}$ $\mathrm{LiPF}_{6} / \mathrm{EC}-\mathrm{DMC}(1: 1 \mathrm{v} / \mathrm{v})$. The electrolyte typically contained $<40 \mathrm{ppm}$ of $\mathrm{H}_{2} \mathrm{O}$ as determined by Karl-Fischer titration. The cells were allowed to stand overnight before being placed on test.

The cells were tested galvanostatically for 20 cycles between voltage limits of $2 \mathrm{~V}$ and $0.01 \mathrm{~V}$ vs. $\mathrm{Li} / \mathrm{Li}^{+}$on an Arbin Corp. Battery Test System at the same charge and discharge rate of 0.5 $\mathrm{mA} / \mathrm{cm}^{2}$. The samples were allowed to rest at open circuit for $600 \mathrm{~s}$ at each voltage limit before the next cycle. Two cells were run for each of the test conditions and the data were averaged. The fade for these tests was defined as the loss in reversible capacity between cycles 11 and 20 divided by 10 (in $\mathrm{mAh} / \mathrm{g}$-cycle). Thus, a more negative number signifies higher fade.

\section{RESULTS AND DISCUSSION}

The chemical composition of the various carbons studied are summarized in Table I, along with the measured weight losses for the samples heated at $1,000^{\circ}$ and $1,300^{\circ} \mathrm{C}$. The results of the electrochemical characterization tests are summarized in Table II, along with data for a

\footnotetext{
${ }^{1}$ Unless otherwise noted, all compositions are in weight percent.
} 
Table I. Composition of Carbons Used in This Study.

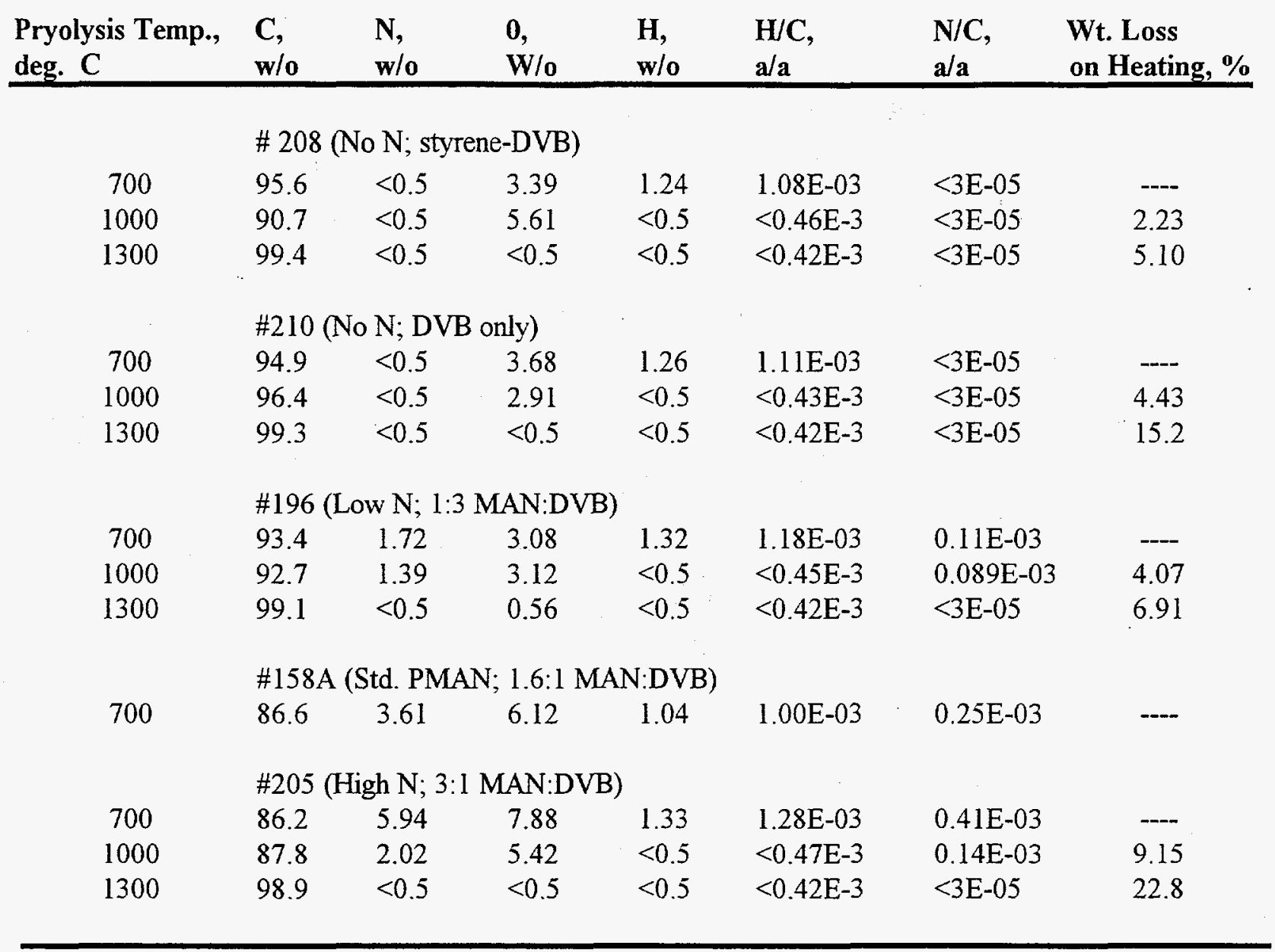

commercial graphite, Lonza KS-6, for comparison purposes. ("Load" means intercalation of $\mathrm{Li}^{+}$, while "Unload" refers to deintercalation.) The reversible and irreversible capacities and the corresponding coulombic efficiencies are plotted as a function of $\mathrm{N}$ content (in $\mathrm{a} / \mathrm{o}$ ) in Figure 1 for the $700^{\circ} \mathrm{C}$ samples. The reversible capacity increased while the irreversible losses gradually decreased with increase in $\mathrm{N}$ content, resulting in an overall improvement in coulombic efficiency.

These results are in marked contrast to those reported by Dahn et al. for precursors based on pyridine, acetonitrile, and benzene [5]. In that work, the $\mathrm{N}$ contents ranged from $<0.1 \%$ for the benzene precursor to $4.06 \%$ for the pyridine precursor and $8.37 \%$ for the acetonitrile precursor. The samples were pyrolyzed at $900^{\circ} \mathrm{C}$ and showed similar first-cycle reversible capacities but increased irreversible losses with increase in $\mathrm{N}$ content. The difference in behavior relative to the PMAN/DVM carbons is attributed to a much higher pyrolysis temperature, the different precursors, and the method of preparation (vapor-phase pyrolysis) that were used.

The fade for the $700^{\circ} \mathrm{C}$ PMAN samples is shown in Figure 2 as a function of $\mathrm{N}$ content (in a/o). As the $\mathrm{N}$ level increased, the fade increased (i.e., became more negative) almost monotonically. Thus, having a high reversible capacity is inadequate if it cannot be sustained for many cycles.

When the $700^{\circ} \mathrm{C}$ samples were heated further, a weight loss of $2.2 \%$ to $9.2 \%$ occurred at $1,000^{\circ} \mathrm{C}$ after five hours in argon. Weight losses of between $3.1 \%$ and $22.8 \%$ were observed 


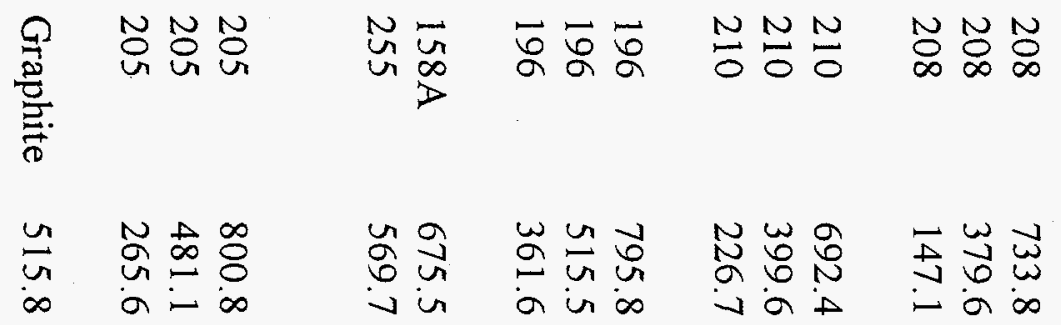

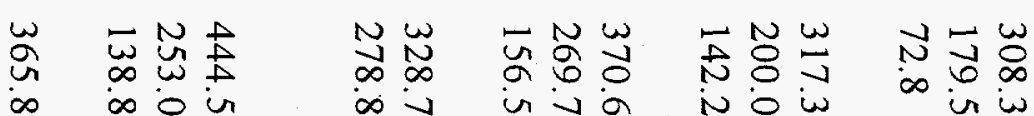

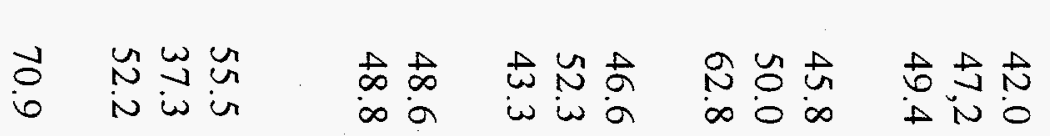

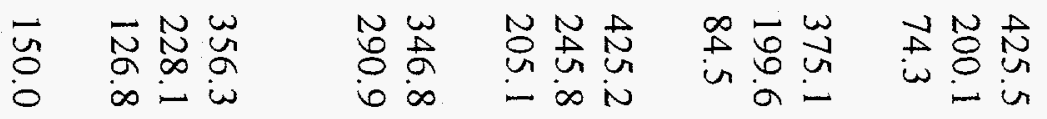

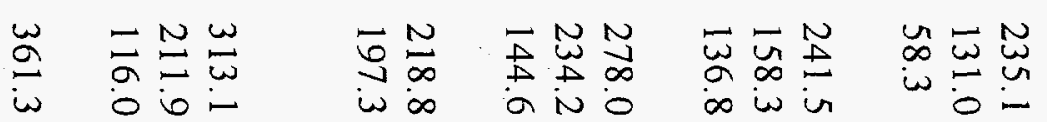

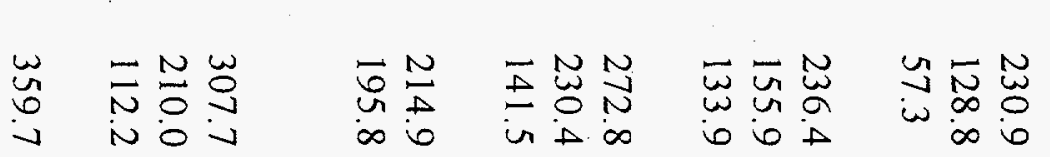

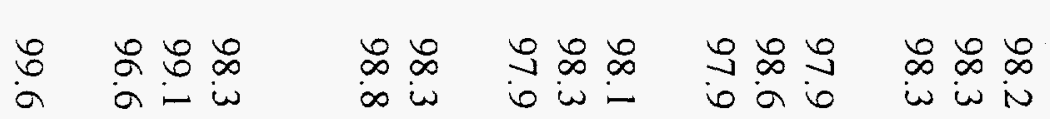

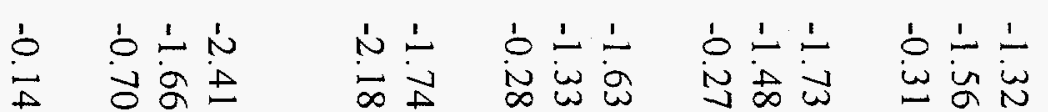

충

3

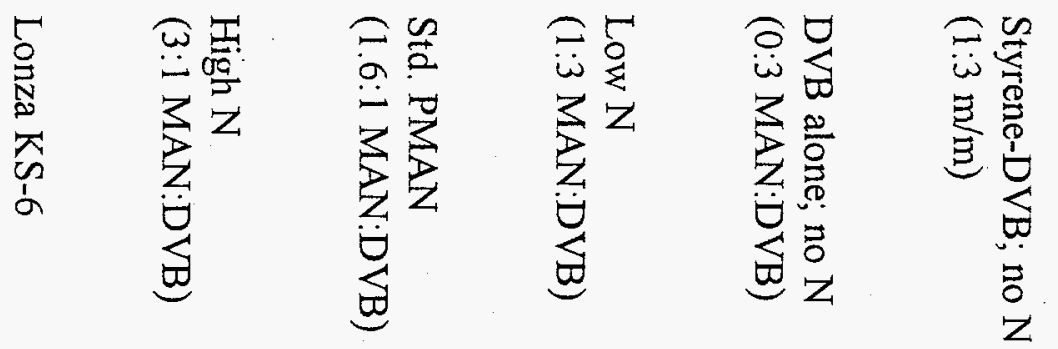
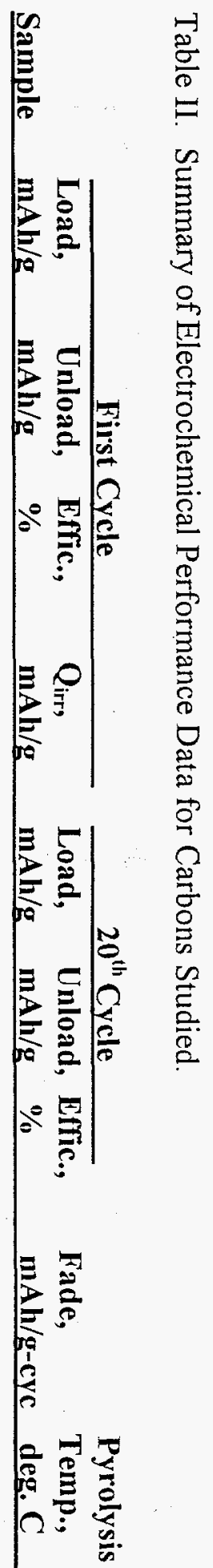


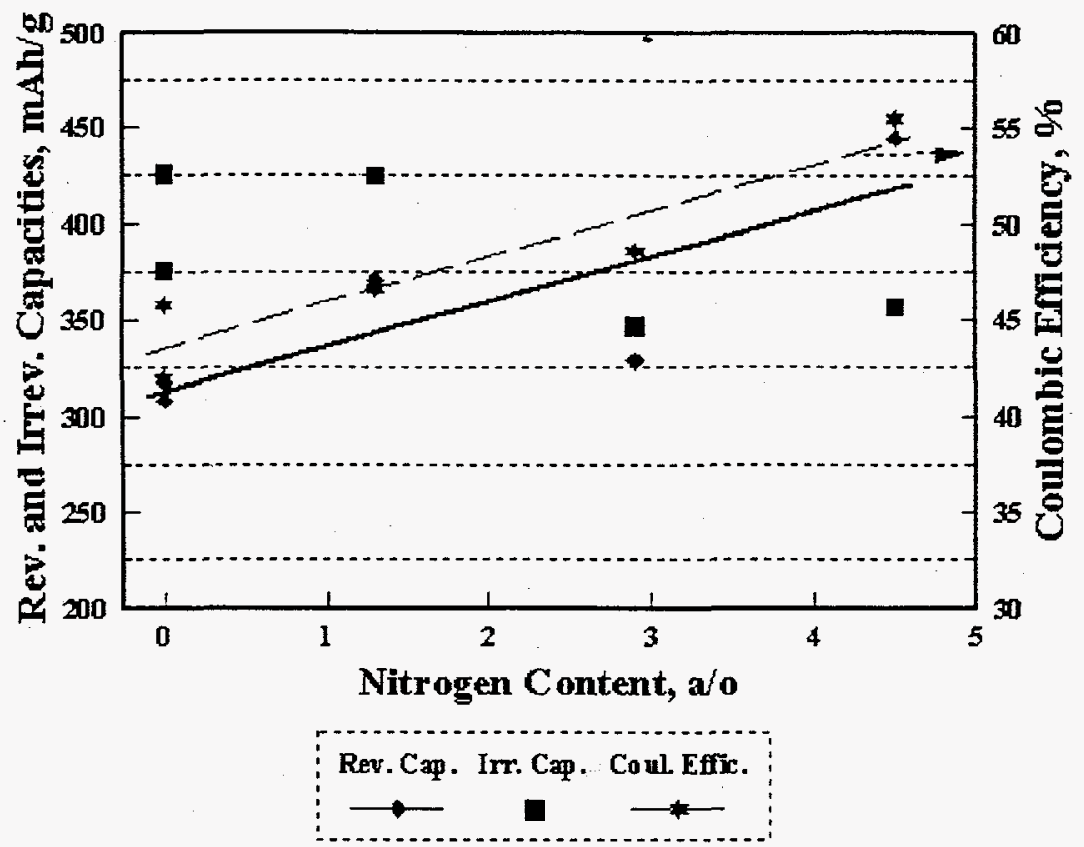

Figure 1. First-Cycle Reversible and Irreversible Capacities and Coulombic Efficiencies as a Function of $\mathrm{N}$ Content for $700^{\circ} \mathrm{C}$ PMAN Samples.

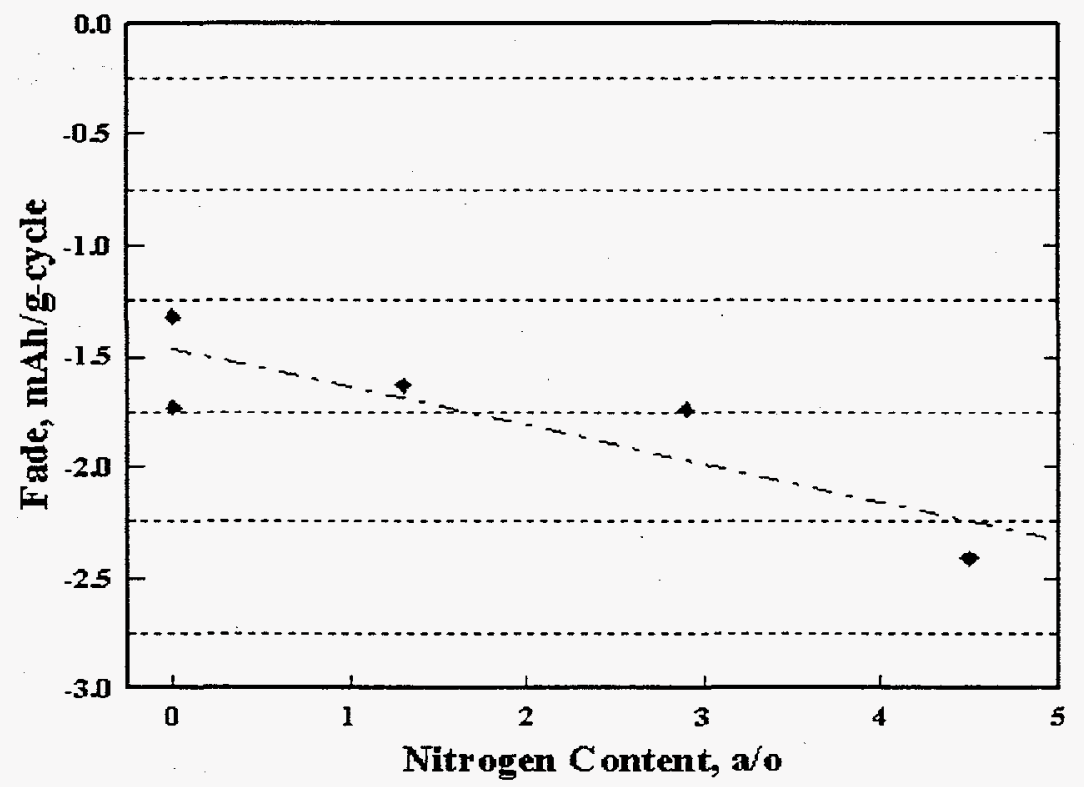

Figure 2. Fade of $700^{\circ} \mathrm{C}$ PMAN/DVB Carbons as a Function of $\mathrm{N}$ Content. for samples that were heated at $1,300^{\circ} \mathrm{C}$ for the same time. All of the $\mathrm{N}$ was removed by heat treatment at $1,300^{\circ} \mathrm{C}$, with significant reduction in the O content, as well, most likely through evolution of $\mathrm{CO}$ and cyano species. After the $1,300^{\circ} \mathrm{C}$ heat treatment, $\mathrm{O}$ and $\mathrm{H}$ were also reduced to below the detection level in all cases but one.

The performance data for samples heated at $1,000^{\circ} \mathrm{C}$, where some residual nitrogen remained, showed an increase in the first-cycle reversible capacities with $\mathrm{N}$ content, but now with a concomitant increase in the irreversible capacities, as reported for samples studied by Dahn and coworkers [5].

At $1,300^{\circ} \mathrm{C}$, where no $\mathrm{N}$ remained, the first-cycle reversible capacities were similar for all carbons except the one containing styrene as a copolymer (\#208). This material had a much lower first-cycle capacity, relative to the other carbons. The irreversible capacities, however, did not converge to a single value, but ranged from 74.3 to 205.1 $\mathrm{mAh} / \mathrm{g}$.

When the reversible and irreversible capacities are plotted vs. $N$ content (in a/o) for all of the carbons (regardless of pyrolysis temperature), a slight increase with increase in $\mathrm{N}$ level is observed, but with considerable scatter in the data. In addition to change in composition, the auxiliary heating also changes the microstructure of the carbons. This results in some localized ordering of the graphene sheets along with a reduction in surface area. This changes the electrochemical properties - especially with regards to irreversible losses. Part of these first-cycle losses are due to passive-film (i.e., SEI layer) formation (from solvent/electrolyte reduction) and 
part results from trapping of $\mathrm{Li}$ in bulk sites. The KS-6 graphite is notable in that it showed a much lower first-cycle irreversible losses and much higher coulombic efficiencies under the same discharge/charge conditions, relative to the disordered carbons examine in this work. It also exhibited the least fade. This is a reflection of its well ordered structure, relative to the hard carbons.

The effects of temperature on the first-cycle reversible capacities for all the carbons studied

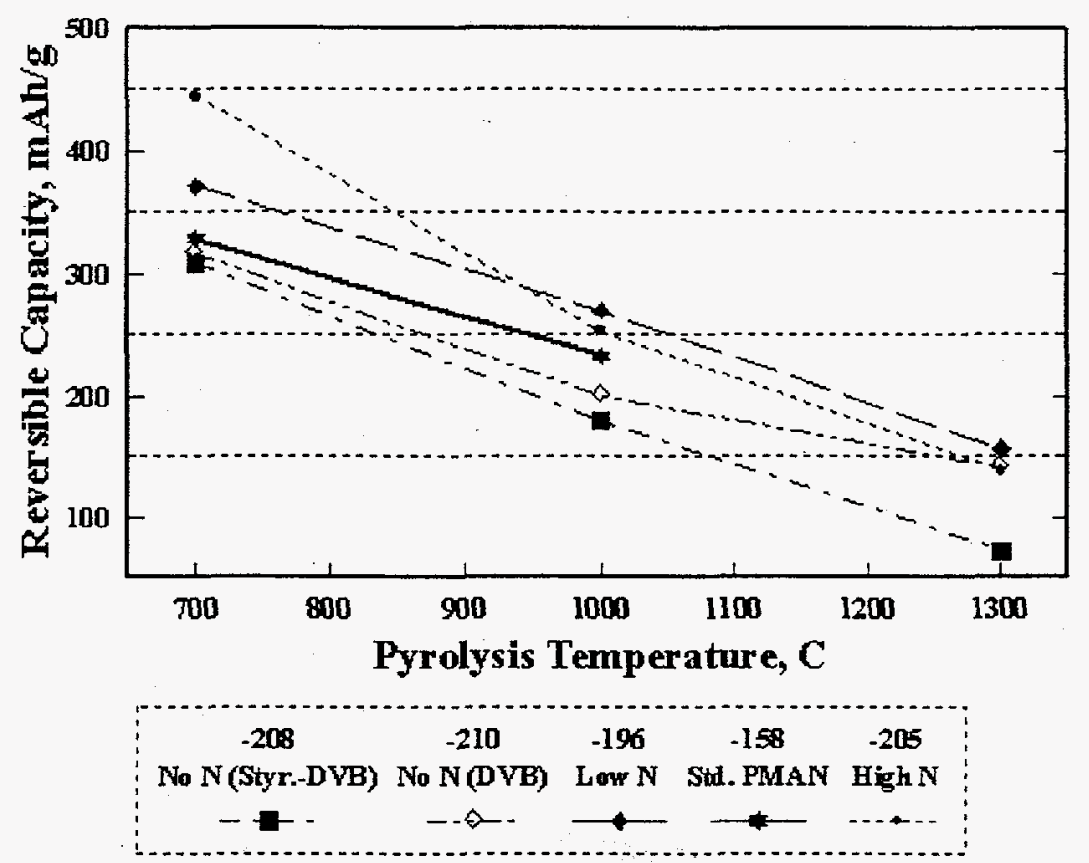

Figure 3. Effect of Pyrolysis Temperature on the First-Cycle Reversible Capacities of PMAN/DVB Carbons. are summarized in Figure 3. These data indicate that the pyrolysis temperature dominates over the actual composition of PMAN/ DVB-based carbons. The capacity decreased almost monotonically with increase in pyrolysis temperature. The same trend was evident with the irreversible capacities for these materials. In general, the coulombic efficiencies increased with a corresponding reduction in fade as the pyrolysis temperature was increased.

Thus, with such disordered carbons, it does not appear possible to attain high reversible capacities without also generating correspondingly high irreversible capacities. They appear to be mutually exclusive. Because of this loss and a high fade, such materials would not be suitable for use in Li-ion cells. After 20 cycles, for example, the KS-6 graphite had the highest reversible capacity (because of its low fade) as well as the highest coulombic efficiency. The $700^{\circ} \mathrm{C}$ high- $\mathrm{N}$ carbon had the next highest reversible capacity but it also showed the highest fade and a lower coulombic efficiency relative to the graphite. This indicates that the passive film may not be as protective for the disordered carbons or that the higher fade may be a result of structural changes in these materials, relative to ordered graphite.

\section{CONCLUSIONS}

The nitrogen content of disordered carbons derived from PMAN/DVB copolymers strongly influences its electrochemical behavior under conditions expected when used as anodes in Li-ion cells. The first-cycle reversible capacities increase and the irreversible capacities decrease as the nitrogen level increases for materials prepared at $700^{\circ} \mathrm{C}$, which results in improved coulombic efficiencies. A first-cycle reversible capacity of $444 \mathrm{mAh} / \mathrm{g}$ is realized at $5.9 \% \mathrm{~N}$. Unfortunately, the tendency to fade while cycling also increases with increase in nitrogen content. This is counter to work reported by others with $\mathrm{N}$-containing carbons prepared at $900^{\circ} \mathrm{C}$ with benzene, pyridine, and acetonitrile precursors. In that work, severe capacity losses were associated with high- $\mathrm{N}$ levels with little effect of the reversible capacities. Differences in composition and form of the precursors and a higher pyrolysis temperature may be responsible. 
Heating the $700^{\circ} \mathrm{C}$ carbon samples at higher temperatures of $1,000^{\circ} \mathrm{C}$ for five hours results in loss of $\mathrm{O}, \mathrm{N}$, and $\mathrm{H}$. Heating at $1,300^{\circ} \mathrm{C}$ removes all the nitrogen and hydrogen, along with considerable oxygen (most likely as $\mathrm{CO}$ and $\mathrm{CN}$-containing species). The electrochemical behavior of these materials differs from that of the $700^{\circ} \mathrm{C}$ carbons, in that both the first-cycle reversible and irreversible capacities decrease almost monotonically with increase in temperature. The corresponding coulombic efficiencies and fade also improve with higher temperature. The heating results in a localized increase in order of the graphene sheets, which has more impact on the electrochemistry than the final composition for these materials. The commercial Lonza KS-6 graphite outperforms the disordered carbons after 20 cycles, with higher reversible capacity and coulombic efficiency. It also has the lowest fade of all the materials studied, most likely because of a more-protective passive film or a more-ordered structure. Because of their high irreversible first-cycle losses, these disordered carbons are not suitable for use as anodes in Li-ion cells.

\section{ACKNOWLEDGMENTS}

The authors wish to thank Marion Hunter for her assistance in preparing and characterizing the carbons. Mike Overstreet and Herb Case assisted in the electrochemical testing.

Sandia National Laboratories is a multiprogram laboratory operated by Sandia Corp., a Lockheed Martin company, for the United States Department of Energy under Contract DE-AC0494AL85000.

\section{REFERENCES}

1. V. Manev, I. Naidevnov, B. Puresheva, P. Zlatilova, and G. Pistoia, J. Power Sources, 55, 211 (1995).

2. W. Xing, J. S. Xue, and J. R. Dahn, J. Electrochem. Soc., 143 (10), 3048 (1996).

3. T. Zheng, Y. Liu, E. W. Fuller, S. Tseng, U. von Sacken, and J. R. Dahn, J.

Electrochem. Soc., 142 (8), 2581 (1995).

4. A. M. Wilson and J. R. Dahn, J. Electrochem. Soc., 142 (2), 326 (1995).

5. J. R. Dahn, A. K. Sleigh, H. Shi, B. M. Way, W. J. Weydanz, J. N. Reimers, Q.

Zhong, and U. von Sacken, Lithium Batteries - New Materials, Development and

Perspectives, G. Pistoia, ed. (Elsevier, New York, 1994), p. 1.

6. Kevin R. Zavadil, Ronald A. Guidotti, and William R. Even, Proc. 1997 Fall MRS Meeting, Boston, MA, 539 (1997).

7. William R. Even, Lawrence W. Peng, Nancy Yuang, Ronald Guidotti, and Thomas Headley, Proc. 1997 Fall MRS Meeting, Boston, MA, 619 (1997).

8. Ronald A. Guidotti and Bryan J. Johnson, Proc. 38th Power Sources Conf., 440 (1998).

9. W. R. Even and D. P. Gregory, MRS Bulletin, 19 (4), 29 (1994). 